Research Article

\title{
Outcome of fracture of intra articular distal femur treated with distal femur locking compression plate
}

\author{
Nirav P. Trivedi*, Rajdeepsinh H. Chauhan, Darshansinh R. Padhiyar, Shreyas P. Gandhi
}

Department of Orthopaedics, C.U. Shah Medical College, Surendranagar, Gujarat, India

Received: 15 October 2015

Accepted: 21 November 2015

*Correspondence:

Dr. Nirav P. Trivedi,

E-mail: Docnirav87@gmail.com

Copyright: ( ) the author(s), publisher and licensee Medip Academy. This is an open-access article distributed under the terms of the Creative Commons Attribution Non-Commercial License, which permits unrestricted non-commercial use, distribution, and reproduction in any medium, provided the original work is properly cited.

\section{ABSTRACT}

Background: Intra articular fracture of the distal femur is a composite and complex injury that poses various challenges for orthopaedic surgeon starting from management of fracture to a protracted recovery of the patient.

Methods: We have done retrospective study of 25 patients with intra articular distal femur fracture operated during the period of 2008 to 2014. NEER score is used as criteria for evaluation of patients.

Results: With use of DFLCP, anatomical reduction and rigid fixation, early mobilization and aggressive physiotherapy can be started with the use of these plates.

Conclusions: Our study shows that distal femur locking compression plate (DFLCP) is the evolving approach to treat distal femur fractures.

Keywords: Distal femur fracture, Distal femur locking compression plate (DFLCP), Intra articular fracture, Less invasive stabilization system (LISS)

\section{INTRODUCTION}

Fracture of distal femur accounts for 7 percent of all femoral fractures and 30 percent of fractures of femur excluding hip fractures. ${ }^{1}$ Distal femoral fractures mainly arise from two different injury mechanisms. (1) High energy trauma mainly sustained in road traffic accidents in younger patient. (2) Low energy trauma, in elderly patients with severe osteoporosis. Since last two decades incidence of this type of fractures has increased a lot due to a rise in road traffic accidents. The management of intra articular distal femur fractures is challenging with wide range of potential complications. In elderly patients, extreme osteoporosis represents a particular problem for anchoring the implant. ${ }^{2}$ The LCP is a single beam construct where the strength of its fixation is equal to the sum of all screw-bone interfaces rather than a single screw's axial stiffness or pull-out resistance as seen in unlocked plates.
Distal femur locking plates can be applied in three different ways:

1. As a conventional dynamic compression plate providing absolute stability.

2. As a "pure" internal fixator providing relative stability by bridging the fracture zone according to less invasive stabilization system (LISS) principles.

3. In combined fashion where both techniques are employed using conventional lag screw as well as locked screws. The implant offers multiple points of fixed-angle contact between the plate and screws in the distal part of femur, theoretically reducing the tendency for varus collapse that is seen with traditional lateral plates. ${ }^{3}$

The purpose of this study is to evaluate the outcome, effectiveness and complications of distal femur fractures, treated by open reduction and internal 
fixation using distal femoral locking compression Plate.

\section{METHODS}

We have done retrospective study of 25 patients with intra articular distal femur fracture operated during the period of 2008 to 2014. All patients are included according to pre-defined inclusion and exclusion criteria.

\section{Inclusion criteria}

1. All patients of age of 18 years or above both male and female.

2. Close or open grade fracture $\mathrm{C} 1, \mathrm{C} 2, \mathrm{C} 3$ according to AO classification. ${ }^{4,5}$

\section{Exclusion criteria}

1. Conservatively treated patients.

2. AO group A and B.

3. Pathological fracture

4. Peri-prosthetic fracture

5. Patients with vascular injury.

Functional grading was done according to pain, function, mobility, and work while radiological grading was done according to varus/valgus deformity and status of union.

\section{Locking compression plate $e^{6,7}$}

Fracture fixation devices with threaded screw holes function as fixed angle device.

It is a pre contoured plate with distal expanded part having multiple holes which allow placement of 4.5 $\mathrm{mm}$ cortical and $5 \mathrm{~mm}$ or $6.5 \mathrm{~mm}$ cancellous screw with locking head providing advantage of

1. Compression of articular fragments

2. Angular stability.

Proximal part has combi-holes which allow placement of either of locking $5.0 \mathrm{~mm}$ or $4.5 \mathrm{~mm}$ cortical screw.

\section{Surgical techniques ${ }^{8,9}$}

1. Position: Patient is placed supine on a radiolucent table with a pillow below the knee. Knee is placed in slight flexion over a small sand bag or a triangular frame.

2. Approach: We commonly used extensile lateral approach for most intra articular distal femoral fracture. By avoiding dissection of the medial soft tissues in the distal femoral metaphyseal region, healing should proceed predictably.

3. Reduction: We first anatomically reduce articular fragments and provisionally stabilize them with $\mathrm{k}$ wires. Then the proper sized plate is selected and the fracture is fixed. Then we insert minimum 5 screws including lag screws and locking head screws in distal expanded part and minimum 4 screws (8cortises) in proximal femoral diaphysis.

We closed joint capsule arthrotomy with absorbable suture, Fascia of vastus lateralis and iliotibial band and subcutaneous tissue closed with absorbable suture. Skin closed with non-absorbable suture. Stiches were removed at 12 th post-operative day.

Depending upon fixation and the bone quality, immediate post-operative knee range of motion (ROM) was started. Patients are asked to come every month for follow up till fracture union. Patient was kept non weight bearing for 12 weeks. Partial to full weight bearing was started at 12 - 14 weeks.

NEER score is used as criteria for evaluation of patients. ${ }^{10}$

\section{RESULTS}

In our study, 25 supracondylar femur fractures with intra articular extension were studied. It is a worldwide fact that intraarticular fracture must be treated with stable internal fixation to get servicible range of movements of knee joint.

- In our study the youngest patient was 18 years and the eldest was 55 years. Average age in our study was 36.36 year.

- With advances in mechanization and acceleration in travel, the incidence of vehicular accident has increased a lot, in our study $96 \%$ of patients having history of RTA and only $04 \%$ of because of fall down.

- The incidence of open fracture was $56 \%$ and close fracture was $44 \%$.

- In our study, the incidence of C2 type and C3 type fracture was same incidence $40 \%$ and the incidence of C1 type was $20 \%$.

- Average injury-surgery interval was 03.04 days.

- Majority of patients were with follow up of more than 24 months. None of the case having less than 6 months follow up.

- In our study, 16 patients having excellent to satisfactory result and 19 patients having $80^{\circ}$ or more knee flexion.

- 5 out of 8 patients having extension lag of $10^{\circ}$ and 2 patients had $5^{\circ}$ extension lag and 1 patient had $20^{\circ}$ extension lag.

- Average month of union was 6.24 month. 24 patient had union and 1 in our study was having nonunion who was treated with bone graft at 9 month. He had union after 12 month.

- In our study, 10 patients out of 25 developed knee stiffness, which is the most common complication in post-operative period in intra-articular fractures. One 
patient developed knee instability. 2 patients had delayed union and 2 patients had infection.

Table 1: Criteria for evaluation of results (NEER Score).

\begin{tabular}{|c|c|}
\hline Functional: & \\
\hline Pain & \\
\hline No Pain & 20 \\
\hline Intermittent / Bad Weather & 16 \\
\hline With Fatigue & 12 \\
\hline Restricted Function & 06 \\
\hline Constant/At Night & $04-00$ \\
\hline Function & \\
\hline As before Surgery & 20 \\
\hline Mild Restriction & 16 \\
\hline Restricted Stairs / Sideway & 12 \\
\hline Severe restriction & 08 \\
\hline Crutches / Brace & $04-00$ \\
\hline Motion & \\
\hline Normal or 135 & 20 \\
\hline 100 & 16 \\
\hline 80 & 12 \\
\hline 60 & 08 \\
\hline 40 & 04 \\
\hline 20 or Less & 00 \\
\hline Work & \\
\hline As Before Injury & 10 \\
\hline Regularly but Handicapped & 08 \\
\hline Altered Work & 06 \\
\hline Light Work & 04 \\
\hline No Work & $02-00$ \\
\hline Anatomical & \\
\hline Gross anatomy & \\
\hline Thickening only & 15 \\
\hline $5^{\circ}$ Angulation & 12 \\
\hline $10^{\circ}$ Angulation / Rotation $/ 2 \mathrm{~cm}$ Shortening & 09 \\
\hline $15^{\circ}$ Angulation/ Rotation/ $3 \mathrm{~cm}$ Shortening & 06 \\
\hline United by Greater Deformity & 03 \\
\hline Nonunion or Chronic Infection & 00 \\
\hline Roentgenogram & \\
\hline Near Normal & 15 \\
\hline $5^{\circ}$ Angulation $/ 0.5 \mathrm{~cm}$ Shortening & 12 \\
\hline $10^{\circ}$ Angulation $/ 1 \mathrm{~cm}$ Shortening & 09 \\
\hline $15^{\circ}$ Angulation $/ 2 \mathrm{~cm}$ Shortening & 06 \\
\hline United by greater deformity & 03 \\
\hline Nonunion or Chronic Infection & 00 \\
\hline NEER score & \\
\hline Excellent & $>85$ \\
\hline Satisfactory & $70-85$ \\
\hline Unsatisfactory & $55-70$ \\
\hline Failure & $<55$ \\
\hline
\end{tabular}

Table 2: Distribution of age.

\begin{tabular}{|ll|l|}
\hline Age & Number & Percentage \\
\hline$<20$ & 3 & $12 \%$ \\
\hline $20-29$ & 6 & $24 \%$ \\
\hline $30-39$ & 5 & $20 \%$ \\
\hline $40-49$ & 4 & $16 \%$ \\
\hline $50-59$ & 7 & $28 \%$ \\
\hline$>60$ & 0 & $00 \%$ \\
\hline
\end{tabular}

Table 3: Type of injury.

\begin{tabular}{|lll|}
\hline Type & Number & Percentage \\
\hline Closed & 11 & $44 \%$ \\
\hline OG 1 & 8 & $32 \%$ \\
\hline OG 2 & 2 & $08 \%$ \\
\hline OG 3 & 4 & $16 \%$ \\
\hline
\end{tabular}

Table 4: Distribution of side of injury.

\begin{tabular}{|lll|}
\hline Right & 15 & $60 \%$ \\
\hline Left & 10 & $40 \%$ \\
\hline
\end{tabular}

Table 5: Mode of injury.

\begin{tabular}{|lll|}
\hline RTA & 24 & $96 \%$ \\
\hline Fall down & 01 & $04 \%$ \\
\hline
\end{tabular}

Table 6: Type of fracture.

\begin{tabular}{|lll|}
\hline Type & Number & Percentage \\
\hline C1 & 5 & $20 \%$ \\
\hline C2 & 10 & $40 \%$ \\
\hline C3 & 10 & $40 \%$ \\
\hline
\end{tabular}

Table 7: Injury surgery interval.

\begin{tabular}{|lll|}
\hline Day & Number & Percentage \\
\hline $0-3$ & 19 & $76 \%$ \\
\hline $4-8$ & 3 & $12 \%$ \\
\hline$>8$ & 3 & $12 \%$ \\
\hline
\end{tabular}

Table 8: Duration of follow up.

\begin{tabular}{|lll|}
\hline Month & Number & Percentage \\
\hline $0-6$ & 0 & $00 \%$ \\
\hline $7-12$ & 1 & $04 \%$ \\
\hline $13-18$ & 1 & $04 \%$ \\
\hline $19-24$ & 2 & $08 \%$ \\
\hline$>24$ & 21 & $84 \%$ \\
\hline
\end{tabular}

- We have evaluated the results of DFLP in distal femur fracture with intra articular extension according to NEER score.

- In our study, 5(100\%) out of 5 patients with type C1 fractures had excellent to satisfactory result, $6(60 \%)$ 
out of 10 patients with type $\mathrm{C} 2$ fractures had excellent to satisfactory result, $5(50 \%)$ out of 10 patients with type $\mathrm{C} 3$ fractures had excellent to satisfactory result.

\section{DISCUSSION}

Distal femur fractures present considerable challenge in management due to

1. Sever soft tissue damage

2. Comminution

3. Fracture extending to knee joint

4. Injury to quadriceps mechanism

Table 9: Bone union time.

\begin{tabular}{|lll|}
\hline Month & Number & Percentage \\
\hline 4 & 2 & $8 \%$ \\
\hline 5 & 10 & $40 \%$ \\
\hline 6 & 7 & $28 \%$ \\
\hline$>6$ & 6 & $24 \%$ \\
\hline
\end{tabular}

Table 10: Post-operative complication.

\begin{tabular}{|lll|}
\hline Complication & Number & Percentage \\
\hline Knee stiffness & 10 & $40 \%$ \\
\hline Knee instability & 01 & $04 \%$ \\
\hline Infection & 02 & $08 \%$ \\
\hline Delayed union & 02 & $08 \%$ \\
\hline Nonunion & 01 & $04 \%$ \\
\hline
\end{tabular}

Table 11: Extension of lag.

\begin{tabular}{|l|l|}
\hline Extension lag & Patient number \\
\hline No & 17 \\
\hline 5 degree & 2 \\
\hline 10 degree & 5 \\
\hline 20 degree & 1 \\
\hline
\end{tabular}

Table 12: Range of movement.

\begin{tabular}{|llllll|}
\hline Type & $\mathbf{1 0 0 ^ { \circ } -}$ & $\mathbf{8 0 ^ { \circ } -}$ & $\mathbf{6 0 ^ { \circ } -}$ & $\mathbf{4 0 ^ { \circ } -}$ & $\mathbf{0}^{\circ}-$ \\
\hline C1 & $\mathbf{1 3 0 ^ { \circ }}$ & $\mathbf{1 0 0 ^ { \circ }}$ & $\mathbf{8 0 ^ { \circ }}$ & $\mathbf{6 0 ^ { \circ }}$ & $\mathbf{4 0}$ \\
\hline C2 & 4 & 1 & 0 & 0 & 0 \\
\hline C3 & 7 & 0 & 1 & 1 & 1 \\
\hline Total & 15 & 3 & 0 & 1 & 2 \\
\hline
\end{tabular}

Before 1970s majority of these fractures were treated conservatively but most traumatologists now prefer internal fixation of such fractures because of poor results of conservative treatment.

These are certain features leading to difficulty in osteosynthesis as follow:

1. Thin cortices

2. Osteopenia

3. Communition and displacement with defect in cortex

4. Wide medullary canal

5. Muscle pulls between flexors and extensors.

6. Cartilage and osteochondral defect

As these fractures are metaphyseal fractures important considerations are achieving length, correction of rotational malalignment and axial alignment of extremity.

Table 13: Evaluation of result (NEER score).

\begin{tabular}{|ccccccc|c|}
\hline Type & Number & $\%$ & Excellent & Satisfactory & Unsatisfactory & Failure \\
\hline C1 & 5 & 20 & 2 & 3 & 0 & 0 \\
\hline C2 & 10 & 40 & 4 & 2 & 2 & 2 \\
\hline C3 & 10 & 40 & 2 & 3 & 3 & 4 \\
\hline Total & 25 & - & 8 & $32 \%$ & $12 \%$ & $24 \%$ \\
\hline$\%$ & - & 100 & $32 \%$ & & & 2 & 2 \\
\hline
\end{tabular}

\section{Clinical cases}

Case 1

A 28 year old male patient having history of RTA, had fracture right intra articular distal femur type C- 3 treated with DFLP, fracture united in 4 months, having range of motion $0^{\circ}-120^{\circ}$. He is able to squat and do crossed leg sitting also.

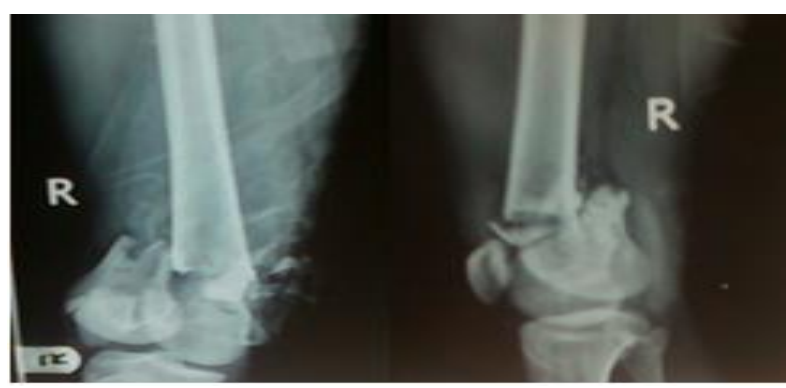

Figure 1: (a) Pre-Operative X-ray. 

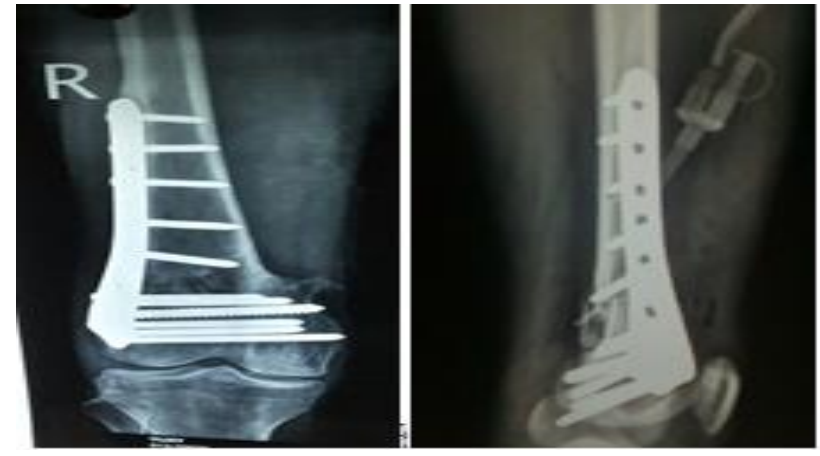

Figure 1: (b) Post-Operative X-ray.

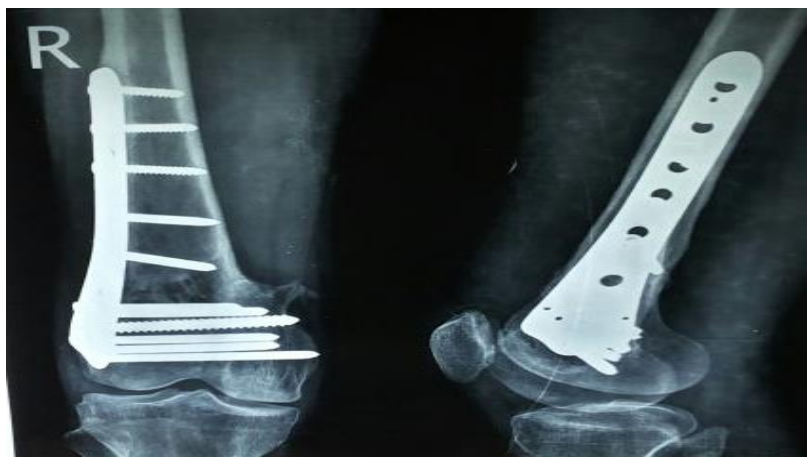

Figure 1 (c): 6 month follow up.

Case 2

A 25 year old male patient with history of RTA had fracture C2 type distal femur, treated with DFLP, fracture united in 5 months, range of motion is 0 to 120 degree. Patient is able to squat with difficulty and does crossed leg sitting.

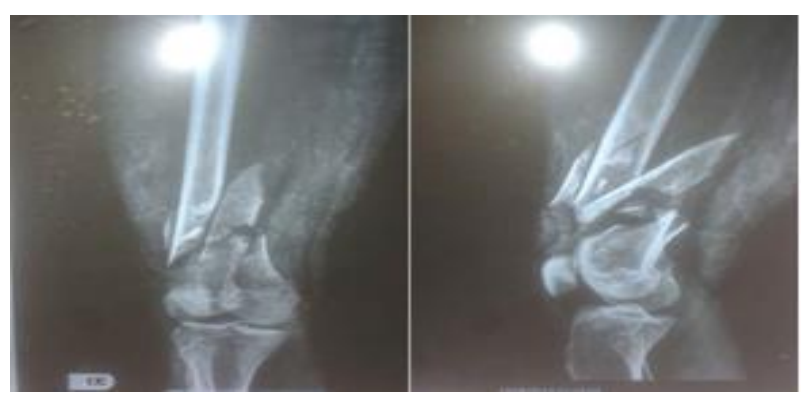

Figure 2 (a): Pre-operative.

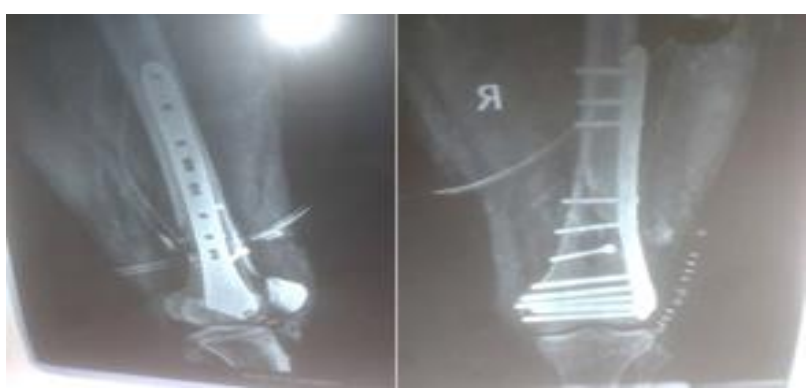

Figure 2 (b):Post-operative.

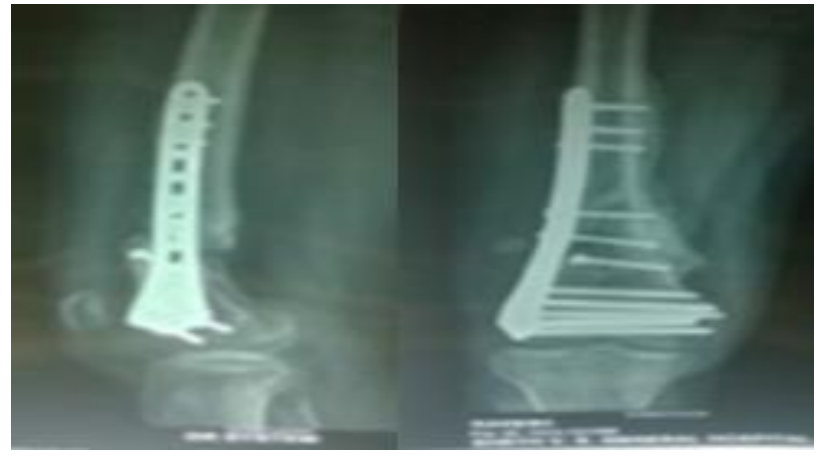

Figure 2 (c): 6 month follow up.

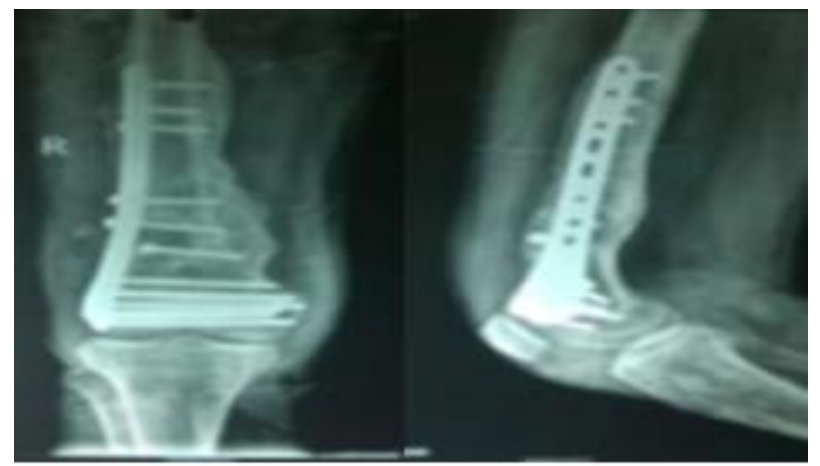

Figure 2 (d): 18 month follow up.

- Management of distal femur fracture is always going to be a challenge for the orthopaedic fraternity.

- Distal femur locking plate provides angular stability and provides multiple options to secure fracture fragments both metaphyseal and articular.

- Anatomical reduction of articular fragments and rigid fixation of reduction of this fracture is must.

- This restores limb length, joint congruity and varusvalgus alignment.

- Along with anatomical reduction and rigid fixation, early mobilization and aggressive physiotherapy can be started with the use of these plates.

Funding: No funding sources

Conflict of interest: None declared

Ethical approval: Not required

\section{REFERENCES}

1. Arneson TJ, Melton LJ, Lewallen DG. Epidemiology of diaphyseal and distal femoral fractures in Rochester, Minnesota, 1965 Clin Orthop Relat Res. 1988;234:188-94.

2. Schandelmaier P, Partenheimer A, Koenemann B. Distal femoral fractures and LISS stabilization. Injury. 2001;32(Suppl 3):SC55-63.

3. Heather V, Theresa H, John S. Failure of LCP condylar plate fixation in the distal part of the femur. J Bone Joint Surg. 2006;88-A:846-53.

4. Muller. Available from URL: https://aotrauma.aofoundation.org/Structure/educati 
on/selfdirectedlearning/referencematerials/classifica tions/Pages/ao-ota-classification.aspx.

5. Kim PH, Leopold SS. Gustilo-Anderson Classification. Clin Orthop Relat Res. 2012;470:3270-3274.

6. Biomechanics and clinical application principles of locking plates: Christoph Sommer, Head Of Traumatology, Kanton hospital, Loestrrase, Switzerland.

7. Egol KA, Kubiak EN,Fulkerson E, Kummer FJ, Koval KJ. Biomechanics of locked plates and screws. J Orthop Trauma. 2004 Sep;18(8):488-93.

8. Bucholz RW, Heckman JD. Rockwood and Green's Fracture in Adults, 8th Edition 2015 Lippincott
Williams and Wilkins, a Walters Kluwer business, USA.

9. Canale and Beaty. Campbell's Operative Orthopaedics, 12th ed. 2012 Mosby, An Imprint of Elsevier.

10. Neer CS, Grantham SA, Shelton ML, Supracondylar fracture of the adult femur. J Bone Joint Surg. 1967;49A:591-613.

Cite this article as: Saxena R, Suneja S, Saxena R, Sharma D, Milton Lal A. Cumulative effect of systemic inflammation and oxidative stress in 40 known cases of active rheumatoid arthritis. Int $\mathbf{J}$ Res Orthop 2015;1:22-7. 